\title{
Analisis status gizi pada balita stunting
}

\author{
Ellyda Rizki Wijhati ${ }^{{ }^{*}}$, Rosmita Nuzuliana ${ }^{2}$, Maulita Listian Eka Pratiwi ${ }^{3}$ \\ ${ }^{1,2,3}$ Prodi DIII Kebidanan Fakultas IImu Kesehatan Universitas ‘Aisyiyah Yogyakarta-Indonesia
}

\begin{abstract}
Nutrition problems are global problems that have a systemic impact on developing countries, including Indonesia. Problems that occur in children with malnutrition not only with body posture, but also have an impact on health both now and in later life. The method used in this study is descriptive with a cross sectional time approach. The sample used was 55 stunting toddlers, with a total sampling. The results showed stunting toddlers who have good nutritional status based on BW / TB are $85.5 \%$, with the factors most related to the level of education of fathers and mothers
\end{abstract}

Keywords: toodler; stunting; nutritional status

Permasalahan gizi adalah permasalahan global yang memiliki dampak yang sistemik pada Negara berkembang termasuk Indonesia. Permasalahan yang terjadi pada anak dengan kekurangan gizi tidak hanya dengan postur tubuh, namun berdampak pada kesehatan baik saat ini maupun pada kehiduan selanjutnya. Metode yang digunakan pada penelitian ini adalah deskriptif dengan pendekatan waktu cros sectional. Sampel yang digunakan adalah sebanyak 55 balita stunting, dengan total sampling. Hasil penelitian didapatkan balita stunting yang memiliki status gizi baik berdasarkan BB/TB adalah $85.5 \%$, dengan faktor yang paling berhubungan dengan tingkat pendidikan ayah dan ibu

Kata Kunci: balita; stunting; status gizi

*Corresponding Author: Ellyda Rizki Wijhati (email: ewijhati@ymail.com) 


\section{Pendahuluan}

Indonesia adalah Negara kepualauan yang luas yang banyak memiliki permasalahan terutama pada status gizi. Indonesia memiliki beban ganda malnutrisi, yaitu terjadinya kekurangan gizi berupa perawakan pendek (stunting), kurus (wasting), dan kelebihan gizi /obesitas (Unicef Indonesia, 2014). Tantangan gizi yang dialami selama periode 1000 HPK yang meliputi 270 hari masa kehamilan dan 730 hari hingga anak usia dua tahun, salah satunya adalah persepsi, komitmen, dan langkah nyata yang terkoordinasi dari pemangku kebijakan, khususnya pemerintah daerah, dalam rangka mewujudkan sumber daya manusia Indonesia yang sehat, cerdas, dan produktif. Untuk mendukung upaya perbaikan gizi, pemerintah secara terus-menerus dan berkesinambungan melakukan berbagai upaya percepatan dan atau penyelamatan perbaikan gizi serta melakukan pemetaan program dan intervensi secara spesifik yang melibatkan berbagai sektor kesehatan dan intervensi sensitif yang dilakukan berupa kegiatan di masyarakat yang secara tidak langsung dapat berpengaruh terhadap status gizi (BAPPENAS, 2013)

Status gizi anak ditentukan dengan beberapa criteria, yaitu kesesuaian berat badan dengan umur (BB/U), kesesuaian panajang badan atau tinggi badan dengan umur $(\mathrm{PB} / \mathrm{U})$, dan kesesuaian berat badan dan tinggi badan (BB/TB). Indeks BB/TB merefleksikan status gizi pada masa kini, sedangkan indeks TB/U merefleksikan status gizi balita pada masa lampau (Ni'mah \& Muniroh, 2015).

Kemenkes RI (2019) menjabarkan pada hasil Riset kesehatan Dasar pada Tahun 2018 aitu data status Gizi balita usia 0-59 bulan di Indonesia untuk kategori sangat kurus 3.5\%, kurus $6.7 \%$, normal $81.8 \%$ dan gemuk $8 \%$. Sedangkan di Daerah Istimewa Yogyakarta menyumbang angka 1,2\% balita sangat kurus, $7,2 \%$ balita kurus, $86 \%$ balita memiliki status gizi normal, dan 4,7\% memiliki status gizi gemuk. Proporsi terbanyak pada balita yang sangat kurus adalah pada usia 24-35 bulan, balita kurus pada usia 0-5 bulan, normal pada ussia 36-59 bulan, dan gemuk pada usia 0-5 bulan. Dan kejadian paling banyak di tingkat pedesaan.

Hasil Riset Kesehatan Dasar (Riskesdas) 2018 menyebutkan bahwa prevalensi balita dengan status gizi wasted/ kurus pada tahun 10,2\% pada tahun 2018. Prevalensi balita gemuk pada tahun 2013 mencapai 11,9\% menjadi 8\% pada tahun 2018 (Rosha, et al., 2016). 
Permasalahan yang terjadi pada anak dengan kekurangan gizi tidak hanya dengan postur tubuh, namun berdampak pada kesehatan baik saat ini maupun pada kehiduan selanjutnya. Status gizi yang buruk juga berdampak terhadap koginitif anak (Dasman, 2019), keterlambatan perkembangan (Leroy \& Frongillo, 2019), dan bisa menyebabkan rendahnya kualitas sumber daya manusia (Dasman, 2019). Hasil penelitian terdahulu menyebutkan bahwa status gizi pada balita dipengaruhi oleh beberapa faktor. Kondisi satus sosial ekonomi keluarga, riwayat pemberian asi eksklusif, pemberian MPASI yang tepat,dan asupan nutrisi yang diberikan (Putri, et al., 2015). Status social ekonomi keluarga akan beradampak pada sumber pendapatan dan daya beli jenis dan variasi makanan yang akan diberikan kepada balitanya.

Sepanjang pengetahuan peneliti, belum terdapat publikasi penelitian yang menganalisis status gizi pada balita stunting diwilayah lokasi penelitian. Sehingga peneliti tertarik melakukan analisis faktor yang berpengaruh terhadap status gizi balita stunting.

\section{Metode}

Jenis Penelitian ini adalah penelitian deskriptif dengan pendekatan waktu cros sectional.
Penelitian ini dilakukan di wilayah kerja Puskesmas Tegal rejo. Variabel peneltian adalah status gizi anak yang dilihat dari kesesuaian berat badan dengan tinggi badan (BB/TB), Tingkat pendidikan orang tua, jenis pekerjaan orang tua, jadwal pemberian MPASI pada balita. Sampel yang digunakan adalah balita yang memiliki riwayat stunting pada balita usia 2-5 tahun, dengan menggunakan total sampling. Jumlah sampel yang didapatkan adalah 55 responden. Alat yang digunakan pada penelitian ini adalah alat pengukur tinggi badan dan berat badan yang sudah dikaliberasi, formulir pencatatan, dan software WHO Anthro untuk identifikasi status gizi anak (BB/TB). Penelitian ini dibantu oleh 5 asisten peneliti. Asisten peneliti diberikan penjelasan/ apersepsi sebelum pelaksanaan pengambilan data. Pengambilan data diawali dengan perijinan dan identifikasi jadwal posyandu balita di seluruh kecamatan Tegalrejo, dan terdapat 47 posyandu balita. Setelah identifikasi diperoleh, peneliti dan asisten peneliti mengunjungi posyandu, izin di masing masing posyandu, melakukan informed concent kepada ibu responden, mengukur Tinggi Badan dan Berat Badan Balita dan mengisi kelengkapan data. Data yang terkumpul dilakukan pengecekan ulang kelengkapan 
data, melakukan entry data, analisis data dasarkan perhitungan BB/TB , $85.5 \%$ memilii menggunakan chi square. status gizi yang normal, dimana $87.3 \%$ lahir dengan berat badan lahir normal, diberikan asi

\section{Hasil dan Pembahasan}

Berdasarkan tabel 1 status gizi anak baik diperoleh dari hasil perhitungan Z-Score berada di -2-+2 Standar Deviasi (SD), dan status gizi buruk adalah berada di $>+2$ SD dan $<-2$ SD. Hasil penelitian status gizi anak stunting bereksklusif sebanyak $58.2 \%$, dan $50 \%$ diberikan MP-ASiyang tepat waktu. Sebanyak $80 \%$ ibu berpendidikan tinggi, dan $60 \%$ ibu tidak bekerja, $100 \%$ ayah bekerja dan $83.6 \%$ tingkat pendidikan ayah tinggi. Pendapatan keluarga 70.9\% termasuk kategori tinggi.

Tabel 1. Karakteristik Responden

\begin{tabular}{lcclll}
\hline Variabel & $\mathrm{f}$ & $\%$ & Variabel & $\mathrm{f}$ & $\%$ \\
\hline Status gizi & & & Pekerjaan ibu \\
Tidak Normal & & & Tidak bekerja & 33 & 60.0 \\
a. Kurus & 3 & 5.5 & Bekerja & 22 & 40.0 \\
b. Sangat kurus & 2 & 3.6 & Pekerjaan ayah & & \\
$\quad$ c. Obesitas & 3 & 5.5 & Bekerja & 55 & 100.0 \\
Normal & 47 & 85.5 & Tidak bekerja & 0 & 0 \\
Berat Badan Lahir & & & Pendapatan keluarga & & \\
Rendah & 7 & 12.7 & Rendah & 16 & 29.1 \\
Normal & 48 & 87.3 & Tinggi & 39 & 70.9 \\
Asi eksklusif & & & Riwayat MP-ASI & & \\
Tidak & 23 & 41.8 & Tidak tepat & 27 & 49.1 \\
Ya & 32 & 58.2 & Tepat & 28 & 50.9 \\
Tingkat pendidikan ibu & & & Tingkat pendidikan ayah & & \\
Rendah & 11 & 20.0 & Rendah & 9 & 16.4 \\
Tinggi & 44 & 80.0 & Tinggi & 46 & 83.6 \\
\hline
\end{tabular}


Tabel 2. Distribusi silang Status Gizi balita dengan variabel lain

\begin{tabular}{|c|c|c|c|c|c|}
\hline \multirow{3}{*}{ Variabel } & \multicolumn{4}{|c|}{ Status Gizi } & \multirow{3}{*}{$P$ value } \\
\hline & \multicolumn{2}{|c|}{ Tidak normal } & \multicolumn{2}{|c|}{ Normal } & \\
\hline & $f$ & $\%$ & $f$ & $\%$ & \\
\hline \multicolumn{6}{|l|}{ Berat Lahir } \\
\hline Rendah & 1 & 1.8 & 6 & 10.9 & \multirow{2}{*}{0.733} \\
\hline Normal & 7 & 12.7 & 41 & 87.3 & \\
\hline \multicolumn{6}{|l|}{ Asi Eksklusif } \\
\hline tidak & 3 & 5.5 & 20 & 36.4 & \multirow{2}{*}{0.553} \\
\hline Ya & 5 & 9.1 & 27 & 49.1 & \\
\hline \multicolumn{6}{|c|}{ Tingkat Pendidikan Ibu } \\
\hline Rendah & 4 & 7.3 & 7 & 12.7 & \multirow{2}{*}{0.042} \\
\hline Tinggi & 4 & 7.3 & 40 & 72.7 & \\
\hline \multicolumn{6}{|c|}{ Tingkat pendidikan Ayah } \\
\hline Rendah & 4 & 7.3 & 5 & 9.1 & \multirow{2}{*}{0.019} \\
\hline Tinggi & 4 & 7.3 & 42 & 76.4 & \\
\hline \multicolumn{6}{|c|}{ Status Pekerjaan Ibu } \\
\hline Tidak Bekerja & 4 & 7.3 & 29 & 52.7 & \multirow{2}{*}{0.401} \\
\hline Bekerja & 4 & 7.3 & 18 & 32.7 & \\
\hline \multicolumn{6}{|c|}{ Pendapatan Keluarga } \\
\hline Rendah & 3 & 5.5 & 13 & 23.6 & \multirow{2}{*}{0.426} \\
\hline Tinggi & 5 & 9.1 & 34 & 61.8 & \\
\hline
\end{tabular}

Tabel 2 menjelaskan bahwa status tingkat pendidikan ibu dan tingkat pendidikan ayah memiliki hubungan secara statistic dengan status gizi anak. Artinya, ibu dan ayah yang berpendidikan tinggi lebih berpeluang lebih tinggi memiliki anak dengan status gizi normal. Berat lahir bayi, pemberian asi eksklusif, pekerjaan ayah dan ibu serta pendapatan keluarga secara statistik tidak signifikan mempengaruhi status gizi anak.

Hasil peneltian lain menyebutkan $85.5 \%$ responden memiliki status gizi normal yaitu berat badan sesuai dengan panjang badannya. Perhitungan berat badan per Panjang Badan (BB/TB) merupakan salah satu cara untuk menentukan status gizi anak. Status gizi tidak normal adalah kondisi anak terlihat kurus, sangat kurus atau bahkan obesitas (Kemenkes RI, 2013). Zat gizi yang dikonsumsi balita akan mempengaruhi status gizi balita.

Gizi yang adekuat menjadi salah satu faktor dalam pencapaian tumbuh kembang yang maksimal. Kekurangan gizi dapat menyebabkan gangguan pertumbuhan dan 
perkembangan dan merubah struktur dan fungsi otak. Kekurangan gizi pada usia dibawah 2 tahun akan menyebabkan sel otak berkurang $15-20 \%$ sehingga anak hanya memiliki kualitas otak $80-85 \%$ (Gunawan, et al., 2011).

Status gizi adalah suatu keadaan tubuh sebagai akibat dari kosumsi makanan. Makanan balita diawali dengan Makanan Pendamping ASI (MP-ASI). MP-ASI adalah makanan atau minuman selain ASI yang diberikan pada masa pemberian makanan peralihan dan disertai dengan pemberian ASI (Ikatan Dokter Anak Indonesia, 2010).

Hasil penelitian menyebutkan tidak ada hubungan pemberian MP-ASI dengan status gizi. Hal ini disebabkan karena responden yang dikaji berusia diatas usia 2 tahun dan tidak di telitinya perilaku pemberian makan, jenis dan keberagaman makanan yang dikonsumsi serta aktivitas yang dilakukan balita sehari hari. Keberagaman makanan yang dikonsumsi berdasarkan beberapa peneltiian memiliki hubungan yang positif dan merupakan predictor yang kuat terhadap buruknya status gizi terutama stunting Jenis makanan yang dikonsumsi anak sangat mempengaruhi status gizi pada anak. Salah satu jenis makanan yang dapat menunjang pertumbuhan dan perkembangan tubuh adalah mikronutrien (mineral dan Vitamin). Mikronutrien yang dibutuhkan dalam tubuh sangat kecil namun berfungsi sangat besar dalam tumbuh kembang balita. Menururut (Candra, 2017) dalam penelitian menjelaskan bahwa pemberian suplementasi mikronutrien mineral seperti seng dan zat besi mampu meningkatkan rata-rata frekuensi makan dari 4.16 kali menjadi 4.8 kali perhari, bahkan apabila kombinasi seng dan fe diberikan sebagai suplementasi makanan maka terdapat kenaikan frekuensi dari 4.16 menjadi 5 kali per hari. Pemberian suplemen ini juga terbukti dapat meningkatkan status gizi balita. Hal ini dikarenakan balita yang memiliki frekuensi makan yang meningkat secara bersamaan akan mengalami peningkatan jumlah asupan energy yang diperoleh dari variasi jenis makanan yang dikonsumsi.

Asi ekskluif adalah suatu periode yang anya memberikan minuman pada bayi berupa air susu ibu (ASI), tidak termasuk airu apalagi akanan yang padat. Pemberian obat ketika bayi sakit masih bisa dikatakan bayi mendapatkan asi eksklusif asalkan dalam pecampuran obat tidak menggunakan bahan selain asi. Komposisi ASI sangat mendukung pertumbuan anak karena anak menjadi jarang sakit, hal ini disebakan adanya antibody baik seluler 
maupun humoral serta enzim dan hormone yang mampu merangsang pertumbuhan dan perkembangan otak. Bayi yang mendapatkan ASI tumbuh lebih cepat pada 2-3 bulan pertama kehidupannya, dan meningkat secara konstan sampai usia 6 bulan. Peningakatan berat badan pada bayi yang diberi ASI dengan susu formula biasanya lebih rendah dari pada bayi yang diberi susu formula. Hal ini disebabkan karena bayi yang mengkonsumsi asi dapat mengatur sendiri jumlah kebutuhan nutrisi yang dibutuhkan sesuai dengan rasa lapar dan haus bayi, namun bayi yang diberikan susu formula kebutuhan nutrisi tergantung dari pengasuh yang memberikan susu tersebut. Susu formula memiliki jumlah kalori yang sangat besar dibanding asi, selain itu dalam susu formula mengadung hormone insulin yang lebih tinggi akan merangsang deposit lemak sehingga resiko obesitas sudah terjadi mulai usia dini (Ikatan Dokter Anak Indonesia, 2010). Namun dalam penelitian ini tidak terdapat hubungan yang signifikan antara pemberian ASI ekslusif dengan status gizi pada balita. Hal ini disebabkan pada usia 2-5 tahun merupakan usia yang rawan terhadap permasalahan gizi pada balita. Kerawanan ini disebabkan karena pada usia ini ASI sudah tidak diberikan lagi dan asupan nutrisi tergantung dari diet yang diberikan oleh ibu (Damayanti \& Muniroh, 2016). Selain itu, faktor yang mempengaruhi status gizi balita terutama balita stunting juga disebabkan karena sanitasi yang kurang baik dan akses pelayanan kesehatan yang kurang memadai (Beal, et al., 2018).

Indaryani, et al. (2010) dalam penelitiannya menyebutkan bahwa terdapat hubungan yang kuat antara status gizi dengan awitan pubertas pada anak perempuan. semakin baik status gizi pada anak semakn dini pubertas terjadi. Status gizi pada penelitian ini ditandai dengan Indeks Masa Tubuh Anak, dengan mengkategorikan gizi kurang, gizi baik Resiko Overweight dan overweigh. Nilai IMT yang lebih tinggi berhubungan dengan awitan pubertas. Kaplowits dalam Indaryani, et al. (2010) menjelaskan bahwa obesitas merupakan salah satu faktor penyebab pubertas dini. Hal ini disebabkan anak yang obesitas mepunyai jaringan lemak yang banyak sehingga kadar leptin dalam darah semakin banyak. Leptin berperan penting dalam merangsang pubertas dan memelihara aksis hipotalamus-hipofisisgonad. Leptin dapat bekerja secara langsung maupun tidak langsung pada neuron yang menghasilkan GnRH di hipotalamus dan meningkatkan produksi GnRH, sehingga 
memulai awitan pubertas melalui sinyal hormonal yang berasal dari jaringan lemak.

Tabel 2 menjelaskan salah satu faktor yang berhubungan dengan status gizi responden adalah tingkat pendidikan ayah $(p=0.019)$ dan tingkat ibu $(p=0.042)$. Schultz dalam (Iroth, et al., 2014) menjelaskan bahwa pendidikan merupakan salah satu upaya dalam peningakatan sumberdaya keluarga dalam efektivitas pemeliharan kesehatan. Semakin tinggi pendidikan semakin mudah seseoranng dalam menyerap informasi, sehingga terjadi peningkatan pengetahuan khususnya dalam pemantauan dan pemeliharaan status gizi anak. ibu dengan pengetahuan kemungkinan besar akan menerapkan pengetahuannya dalam proses pengasuhan anak khusunya dalam memberikan makanan sesuai dengan kebutuhan zat gizi yang diperlukan balita. Penelitian ini juga sejalan penelitian yang judul "Risk factors of stunting in children aged 24-59 months" menemukan hasil bahwa faktor pendidikan ayah ibu, tinggi badan ibu $<150 \mathrm{~cm}$, usia ibu saat hamil serta panjang bada lahir terbukti secara statistic berpengaruh pada status gizi balita, terutama pada perawakan yang pendek (Manggala, et al., 2018).

Status sosial ekonomi merupakan segala sesuatu yang berkaitan dengan pemenuhan kebutuhan secara umum yang ada di masyarakat dan dikaitkan dengan pendidikan, pekerjaan dan pemenuhan kebutuhan hidup. Masyarakat menggolongkan status sosial ekonomi menjadi tiga kedudukan yaitu atas menengah dan bawah (Wenas \& Opod, 2015). Kondisi sosial ekonomi seseorang merupakan salah satu faktor umum yang dapat mendorong terjadinya kesenjangan (disparity) antara satu dengan yang lain. Pada penelitian ini status gizi tidak dipengaruhi oleh pekerjaan dan pendapatan orang tua. pekerjaan dan pendapatan orang tua seringkali dinyatakan dengan keadaan social ekonomi keluarga. Hal ini tidak sejalan dengan peneltian Indaryani, et al. (2010), yang menyebutkan bahwa kondisi pendapatan keluarga yang cukup akan lebih mudah mendapatkan jenis makanan yang sesuai kebutuhan gizi anak baik secara kualitas maupun kuantitas. Orang tua akan mampu memenuhi kebutuhan protein hewani dan sumber makanan yang lain.

Tabel 2 menjelaskan salah satu faktor yang berhubungan dengan status gizi balita adalah tingkat pendidikan ayah $(p=0.019)$ dan tingkat ibu ( $p=0.042$ ). Schultz dalam (Iroth, et al., 2014) menjelaskan bahwa pendidikan merupakan salah satu upaya dalam peningakatan sumberdaya keluarga dalam 
efektivitas pemeliharan kesehatan. Semakin tinggi pendidikan semakin mudah seseoranng dalam menyerap informasi, sehingga terjadi peningkatan pengetahuan khususnya dalam pemantauan dan pemeliharaan status gizi anak. ibu dengan pengetahuan kemungkinan besar akan menerapkan pengetahuannya dalam proses pengasuhan anak khusunya dalam memberikan makanan sesuai dengan kebutuhan zat gizi yang diperlukan balita.

Permasalahan yang terjadi pada anak kekurangan gizi ini bukan hanya pada postur tubuh yang kurus atau gemuk namun bisa berdampak pada kognitif anak Anak yang memiliki gizi buruk pada saat balita namun mengalami cath-up pada masa anak anak akan memiliki intelektual yang lebih tinggi dari pada anak yang tidak mencapai cath-up pada pertumbuhan (Crookston et al., 2010). Kondisi rendahnya kogitif anak akan mengakibatkan rendahnya prestasi anak dan sumber manusia yang berkualitas rendah (Dasman, 2019). Disisi lain anak dengan status gizi buruk lebih mudah terkena penyakit degenerative karena mengalami masalah perkebangan sistem hormolnal insulin dan glucagon pada pancreas yang mengatur keseimbangan dan metablisme glukosa. Sehingga pada asaat dewasa akan terjadi kelebihan intake kalori, keseimbangan gula dara lebih cepat terganggu dan pembentukan jaringan lemak tubuh (lipogenesis) juga lebih mudah kodisi status gizi buruk ini akan berperan dalam meningkatka beban gizi ganda terhadap peningkatan penyakit kronis. Kedua dampak tersebut apabila tidak diberikan intervensi yang cukup maka akan menyebabkan rendahnya kualitas sumber daya manusia rendah (Dasman, 2019).

Leroy and Frongillo (2019) dalam literature reviewnya menjelaskan bahwa anak yang memiliki ukuran tubuh yang lebih kecil akan mengurangi aktivitas motorik sehinggga membatasi kemampuan anak dalam mengeskplorasi dan mengkases stimulasi perkembangan bahasa, sosioemosional dan kognitif. Keterlambatan pada perkembangan motorik lebih disebabkan karena keseimbangan tubuh, kekuatan otot dan daya tahan tubuh yang kurang, serta faktor mielinisasi. Mielinisasi yaitu proses pembentukan mielin dalam syaraf otak. Mielin sangat penting dalam fungsi motorik normal (yaitu gerakan seperti berjalan), fungsi sensorik (misalnya mendengar, melihat atau merasakan sensasi nyeri) dan kognisi (misalnya memperoleh dan mengingat kembali pengetahuan). Dalam pembahasan pada jurnal ini menyebutkan ukuran tubuh yang kecil 
bukan berarti postur tubuh yang pendek. Anak dengan postur tubuh yang pendek akan mengalami keterbatasan dalam motorik kasar, bahasa dan koginif jika pada proses keseimbangan tubuh, daya tahan tubuh dan mielinisasi mengalami gangguan.

Adiningsih, et al., (2018) dalam hasil penelitian menunjukkan adanya hubungan antara status gizi buruk terutama stunting dan keterlambatan pertumbuhan gigi. Terdapat perbedaan signifikan jumlah anak yang belum tumbuh gigi dan umur tumbuh gigi pertama pada kedua kelompok $(p<0,05)$. Pertumbuhan gigi dimulai dari dalam gusi berkorelasi dengan derajat status gizi (Flores-Mir, et al., 2005). Frekuensi diare yang sering menyerang balita stunted menyebabkan asupan kalsium bersama mineral lain berkurang sehingga pertumbuhan balita makin terganggu

\section{Kesimpulan}

Hasil penelitian ini menunjukkan bahwa penilaian status gizi balita berdasarkan BB/TB balita stunting menunjukkan status gizi balita yang normal. Status gizi balita berhubungan secara signifikan dengan tingkat pendidikan ayah dan ibu. Artinya semakin tinggi tingkat pendidikan orang tua semakin baik status gizi balita tersebut.

\section{Daftar Pustaka}

Adiningsih, S., Rifqi, M. A., \& Muthmainnah. (2018). Pengaruh Pemberian Biskuit Terhadap Perubahan Berat Badan Balita Stunting Usia 6-17 Bulan. In Widyakarya Nasional Pangan dan Gizi (WNPG) "Percepatan Penurunan Stunting melalui Revitalisasi Ketahanan Pangan dan Gizi dalam Rangka Mencapai Tujuan Pembangunan Berkelanjutan." Jakarta: LIPI.

BAPPENAS. (2013). Pedoman perencanaan program gerakan nasional percepatan perbaikan gizi dalam rangka seribu hari pertama kehidupan.

Beal, T., Tumilowicz, A., Sutrisna, A., Izwardy, D., \& Neufeld, L. M. (2018). A review of child stunting determinants in Indonesia. Maternal and Child Nutrition, 14(4), 110.

Candra, A. (2017). Suplementasi Mikronutrien dan Penanggulangan Malnutrisi pada Anak Usai dibawah Lima Tahun (Balita). $J N H, 5(3), 1-8$.

Crookston, B. T., Penny, M. E., Alder, S. C., Dickerson, T. T., Merrill, R. M., Stanford, J. B., ... Dearden, K. A. (2010). Children Who Recover from Early Stunting and Children Who Are Not Stunted Demonstrate Similar Levels of Cognition $1,2$. The Journal of Nutrition, (15), 19962001.

Damayanti, R. A., \& Muniroh, L. (2016). Perbedaan Tingkat Kecukupan Zat Gizi dan Riwayat Pemberian Asi Eksklusif pada balita Stunting dan Non Stunting. Media Gizi Indonesia, 11(1), 61-69.

Dasman, H. (2019). Empat dampak stunting bagi anak dan negara Indonesia. The Conversation (Disipln IImiah, Gaya Jurnalistik), 22-24. 
Gunawan, G., Fadlyana, E., \& Rusmil, K. (2011). Hubungan Status Gizi dan Perkembangan anak Usia 1-2 tahun. Sari Pediatri, 13(2), 142-146.

Ikatan Dokter Anak Indonesia. (2010). Indonesia Menyusui. (R. Suradi, B. Hegar, I. gusti N. A. Pratiwi, A. N. S. Marzuki, \& Y. Ananta, Eds.). Jakarta: Badan Penerbit IDAI.

Indaryani, W., Susanto, R., \& Susanto, J. (2010). Huungan Awitan Pubertas dan Status Sosal Ekonomi serta Status Gizi pada anak Perempuan. Sari Pediatri, 11(5), 610.

Iroth, V., Malonda, N. S. H., \& Kapantow, N. H. (2014). Hubungan Antara Status Sosial Ekonomi dengan Status Gizi pada Anak Usia 24-59 Bulan. Jurnal Kesmas, 7(4).

Kemenkes RI. (2013). Pedoman Pelaksanaan Stimulasi Deteksi dan Intervensi Dini Tumbuh Kembang Anak di Tingkat Pelayanan Kesehatan Dasar. Jakarta: Departemen Kesehatan Republik Indonesia.

Kemenkes RI. (2019). Laporan Nasional Riskesdas 2018. Jakarta: Lembaga Penerbit Badan Penelitian dan Pengambembangan Kesehatan.

Leroy, J. L., \& Frongillo, E. A. (2019). Perspective : What Does Stunting Really Mean?
A Critical Review of the Evidence, 196204.

Manggala, A. K., Kenwa, K. W. M., Kenwa, M. M. L., Sakti, A. A. G. D. P. J., \& Sawitri, A. A. S. (2018). Risk factors of stunting in children aged 24-59 months. Paediatrica Indonesiana, 58(5), 205-212.

Ni'mah, C., \& Muniroh, L. (2015). Hubungan Tingkat Pendidikan, Tingkat Pengetahuan dan Pola Asuh Ibu dengan Wasting dan Stunting pada Balita Keluarga Miskin. Media Gizi Indonesia, 10(1), 8490.

Putri, R. F., Sulastri, D., \& Lestari, Y. (2015). Artikel Penelitian Faktor-Faktor yang Berhubungan dengan Status Gizi Anak Balita di Wilayah Kerja Puskesmas Nanggalo Padang. Jurnal Kesehatan Andalas, 4(1), 254-261.

Rosha, B. C., Sari, K., SP, I. Y., Amaliah, N., \& Utami, N. H. (2016). Peran Intervensi Gizi Spesifik dan Sensitif dalam Perbaikan Masalah Gizi Balita di Kota Bogor. Buletin Penelitian Kesehatan, 44(2), 127-138.

Unicef Indonesia. (2014). Nutrisi. Retrieved November 14, 2019, from https://www. unicef.org/indonesia/id/nutrisi

Wenas, G. E., \& Opod, H. (2015). Hubungan Kebahagiaan Dan Status Sosial Ekonomi. E-Biomedik (EBm), 3(April), 1-7. 
This page itentionally left blank. 